\title{
2020 Vision? A case of malignant hypertension
}

\author{
Richard Tanner (ㄷ),' Bryan O'Sullivan, ${ }^{1}$ Liam Bourke, ${ }^{2}$ Peter Kelly'
}

'Department of Cardiology, Cork University Hospital Group, Cork, Ireland

${ }^{2}$ Department of Ophthalmology, Cork University Hospital Group, Cork, Ireland

\section{Correspondence to}

Dr Richard Tanner;

richard.tanner@umail.ucc.ie

Accepted 23 July 2020
Check for updates

(c) BMJ Publishing Group Limited 2020. No commercial re-use. See rights and permissions. Published by BMJ.

\footnotetext{
To cite: Tanner $R$,

O'Sullivan B, Bourke L,

et al. BMJ Case Rep

2020;13:e236617.

doi:10.1136/bcr-2020

236617
}

\section{DESCRIPTION}

A 48-year-old man with no medical history presented to the emergency department with reduced visual acuity over the preceding 4 weeks. He denied headaches, diplopia, dyspnoea or chest pain. Malignant range hypertension was noted with an initial reading of $249 / 165 \mathrm{~mm} \mathrm{Hg}$ (mean arterial pressure (MAP) $193 \mathrm{~mm} \mathrm{Hg}$ ), which persisted on repeat measurements.

Cardiorespiratory and neurological examination were unremarkable except for reduced visual acuity (6/60 in the left eye and 6/60 in the right eye using Snellen chart). Subsequent funduscopy demonstrated grade IV hypertensive retinopathy which was confirmed on retinal photography, figure 1 . Stage IV hypertensive retinopathy is defined (Keith Wagener Barker classification) by the presence of papilloedema in addition to the features of stage III hypertensive retinopathy namely, intraretinal 'flame' and 'blot' haemorrhages, arteriolar narrowing and cotton wool spots (infarcts due to arteriolar disease). Funduscopy also found an increased light reflex (silver wiring) which likely represents concentric laminar thickening from chronic hypertension.

An arterial line was placed, and intravenous labetalol was commenced. In keeping with European Society of Cardiology (ESC) 2018 arterial hypertension guidelines and uptodate recommendations on hypertensive emergency, we targeted a reduction in MAP of $10 \%-20 \%$ in the first hour and a further $10 \%$ over the following 24 hours. ${ }^{1}$ A controlled reduction in blood pressure (BP) was planned as there was no indication to rapidly reduce his BP (aortic dissection, intracranial haemorrhage, acute heart failure, acute coronary event, encephalopathy) and to avoid cerebral watershed infarcts. BP improved to $150-165 / 90-100 \mathrm{~mm} \mathrm{Hg}$ on intravenous labetalol after 72 hours, and he was transitioned to oral anti-hypertensives. Ultimately, BP on discharge was 128/95 mm Hg.

Initial investigations revealed non-proteinuric moderate renal impairment (estimated glomerular filtration rate (eGFR) $57 \mathrm{~mL} / \mathrm{min} / 1.73 \mathrm{~m}^{2}$ ) and an ECG without evidence of left ventricular hypertrophy or ischaemia. A CT brain scan found deep and periventricular white matter microvascular disease and old infarcts in both corona radiata.

Blood testing for renin aldosterone ratio, lipid profile, HbA1C, urine for protein creatinine ratio, transthoracic echocardiogram (TTE), MRI of renal arteries and urine collection for urinary catecholamines. All were within normal limits except for moderate left ventricular hypertrophy on TTE. Visual acuity improved throughout his hospital stay, and he was discharged 12 days later with advice on lifestyle changes and an anti-hypertensive regime of

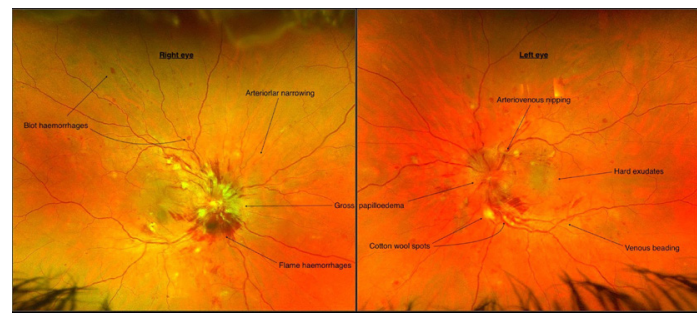

Figure 1 Grade IV hypertensive retinopathy on presentation to the emergency department.

olmesartan $40 \mathrm{mg}$, verapamil SR $360 \mathrm{mg}$, doxazosin XL $16 \mathrm{mg}$, spironolactone $50 \mathrm{mg}$ and hydralazine $25 \mathrm{mg}$ four times a day. A 24 hours ambulatory BP monitor found an average BP of $132 / 93 \mathrm{~mm} \mathrm{Hg}$ 3 months after discharge.

Hypertensive retinopathy has a prevalence of $3 \%-14 \%$ in non-diabetic adults aged $\geq 40$ years with focal arteriolar narrowing (7\%) and arteriovenous nicking $(12 \%)$ being the most common finding and cotton wool spots being uncommon $(0.3 \%) .{ }^{23}$ The presence of hypertensive retinopathy correlates with an increased risk of ischaemic stroke (adjusted relative risk 2.58, 95\% CI (1.59-4.2)) and predicts long-term risk of stroke independent of $\mathrm{BP}$ control. ${ }^{45}$ Moreover, an adjusted analysis found retinopathy to predict a doubling of coronary artery disease events irrespective of BP control. ${ }^{6}$ Similarly, retinopathy was found to be an independent

\section{Patient's perspective}

I never considered that high blood pressure could be the cause of my deteriorating vision. I also thought that one would feel unwell if they had very high blood pressure which was not the case for me.

\section{Learning points}

- Funduscopy is a fundamental part of assessing hypertensive patients for end-organ damage and offers a unique opportunity to visualise the microvasculature affected by hypertension

- The presence of hypertensive retinopathy can help risk-stratify a patient when assessing future risk of stroke, coronary artery disease and heart failure, even if hypertension is well controlled

- On admission, patients need a clearly documented plan as to how the patient's blood pressure will be managed to avoid complications due to rapid blood pressure correction. 
predictor of congestive heart failure (RR 1.96, 95\% CI (1.51$2.54)){ }^{7}$ These finding in addition to the ESC recommendation of funduscopy for all patients with grade II or III hypertension (all with diabetes) support funduscopy as an essential component in assessing a patient with hypertension.

Acknowledgements To the patient for consenting to use his clinical information to enhance medical education.

Contributors Each author has contributed to this manuscript and approved the final version. RT is the lead author and wrote the image report in conjunction with BO'S. LB prepared the main image for presentation, annotated the image and critically reviewed the image report. PK was the senior author and guided how the article should be written and provided critical appraisal.

Funding The authors have not declared a specific grant for this research from any funding agency in the public, commercial or not-for-profit sectors.

Competing interests None declared.

Patient consent for publication Obtained.

Provenance and peer review Not commissioned; externally peer reviewed.

\section{ORCID iD}

Richard Tanner http://orcid.org/0000-0002-2857-6576

\section{REFERENCES}

1 Williams B, Mancia G, Spiering W, et al. 2018 ESC/ESH guidelines for the management of arterial hypertension. Eur Heart J 2018;39:3021-104.

2 Jeganathan VSE, Cheung N, Tay WT, et al. Prevalence and risk factors of retinopathy in an Asian population without diabetes: the Singapore Malay eye study. Arch Ophthalmol 2010;128:40-5.

3 Kawasaki R, Cheung N, Mosley T, et al. Retinal microvascular signs and 10-year risk of cerebral atrophy: the Atherosclerosis risk in communities (ARIC) study. Stroke 2010;41:1826-8.

4 Wong TY, Klein R, Couper DJ, et al. Retinal microvascular abnormalities and incident stroke: the Atherosclerosis risk in Communities study. Lancet 2001;358:1134-40.

5 Ong Y-T, Wong TY, Klein R, et al. Hypertensive retinopathy and risk of stroke. Hypertension 2013;62:706-11.

6 Duncan BB, Wong TY, Tyroler HA, et al. Hypertensive retinopathy and incident coronary heart disease in high risk men. Br J Ophthalmol 2002;86:1002-6.

7 Wong TY, Rosamond W, Chang PP, et al. Retinopathy and risk of congestive heart failure. JAMA 2005;293:63-9.

Copyright 2020 BMJ Publishing Group. All rights reserved. For permission to reuse any of this content visit

https://www.bmj.com/company/products-services/rights-and-licensing/permissions/

BMJ Case Report Fellows may re-use this article for personal use and teaching without any further permission.

Become a Fellow of BMJ Case Reports today and you can:

- Submit as many cases as you like

- Enjoy fast sympathetic peer review and rapid publication of accepted articles

- Access all the published articles

- Re-use any of the published material for personal use and teaching without further permission

Customer Service

If you have any further queries about your subscription, please contact our customer services team on +44 (0) 2071111105 or via email at support@bmj.com.

Visit casereports.bmj.com for more articles like this and to become a Fellow 